\title{
Good Governance Practices and Challenges in Local Government of Ethiopia: The Case of Bonga Town Administration
}

\author{
Wasihun Bezabih Bekele ${ }^{* 1}$ \& Fikre Yohanes Ago ${ }^{1}$
}

* Corresponding Author

E-mail: wbezabih99@mail.com

1. Mizan-Tepi University, Department of Civics and Ethical Studies, Mizan-Aman, Ethiopia.

\section{Article Info}

Received: October 9, 2020

Revised: November 20, 2020

Accepted: November 30, 2020

\subsection{3/repam.2020.6}

\section{How to cite}

Bekele W. B. \& Ago F. Y. (2020). Good Governance Practices and Challenges in Local Government of Ethiopia: The Case of Bonga Town Administration. Research in Educational Policy and Management, 2(2), 97-128.

\section{https://doi.org/10.46303/repam.2020.6}

\section{Copyright license}

This is an Open Access article distributed under the terms of the Creative Commons Attribution 4.0 International license (CC BY 4.0).

\begin{abstract}
This study sought to assess the practice and challenges of good governance in Bonga Town Administration. A descriptive research method was utilized. Respondents are selected by purposive and convenience sampling techniques. Quantitative data was gathered through a questionnaire. Pertinent to qualitative information, structured interview, and FGD are employed. Then, data analyzed through quantitative and qualitative methods. Finally, the study disclosed a low level of accountability and transparency in the town administration. Pervasive corruption is also perceived as a key governance problem in the town; however, due to fear of reprisal citizens lack experience in exposing corruption. In sum poor service delivery, the gap between local government representatives and the town people, high level of rent-seeking, weak political leadership, lack of timely response for a public interest, and public disengagement in shared affairs were found to be challenges of good governance. Henceforth, based on the findings, it is concluded that the current good governance practice in Bonga Town Administration is weak and identified with a high level of rent-seeking among public servants as well as appointed and elected authorities. This research argues for the existence of governance which ensures public engagement in decision making and prioritization of shared problems, accompanied by transparent and accountable administration. KEYWORDS

Governance; good governance; local government; local governance; town administration.
\end{abstract}




\section{INTRODUCTION}

In the contemporary world, good governance has become a catchphrase and it is also frequently mentioned as one ingredient of economic growth and poverty reduction. As the researchers learned from the literature the use of the word "good governance" first appeared in a 1989 World Bank (WB) report on Sub-Saharan Africa. As indicated in AfDB(1999) a 1989 WB report on "Sub-Saharan Africa: From crisis to sustained growth", raised the issue of governance. It was following this report that the idea of good governance is frequently pronounced among aid agencies as well as countries regarding development and conditionality for aid provision. As well expressed by Grindle(2010), for the millions of people throughout the world who live in conditions of public insecurity and instability, corruption, abuse of the law, public service failure, poverty, and inequality, good governance is a mighty beacon of what ought to be.

However, there are different views and arguments on the good governance agenda between proponents and opponents of the idea (Gisselquist, 2012). Beyond the argument, there is a widespread consensus that "good governance" is a necessary condition to sustain economic development and ensure the prosperity of the country. Henceforth, developing countries are striving for promoting good governance at all government levels. In Africa too, good governance has got widespread attention, indeed African governments have established various strategies to promote good governance. Ethiopia is not an exception from this consensus and therefore GOE recognized the importance of good governance for bringing sustainable development. According to MOFED, (2009) Ethiopia has, over the last several years, began implementing major reform programs to empower citizens as well as enhances public sector efficiency, effectiveness, transparency, and accountability. In doing so the good governance package has been established to promote good governance. The package attempts to enhance good governance including participation, consensus building, gender equality, responsiveness, transparency, accountability, equity and fairness, the rule of law, and efficiency and effectiveness. Therefore, several measures were taken to improve local governance including awareness-raising campaigns, issuing directives and codes of conduct, changing the number and composition of councilors, appointment of Kebele managers, complaints handling officers, and participation of membership-based grass-root organizations(MoFED, 2009).

The existing emphasis on good governance in Africa, Ethiopia inclusive, is because of the widespread belief that "good governance" is the key to improving development outcomes. Today among politician's and academic researchers of the world, there is a growing tendency of associating good governance with lower levels of corruption, higher levels of bureaucratic professionalism, higher life expectancy, better water quality, lower poverty, and stronger economic growth (Holmberg et al. 2009, cited in Rodden\& Wibbels, 2012).

According to UNDP, 'Good governance refers to governing systems which are capable, responsive, inclusive, and transparent. All countries developed and developing Africa inclusive 
need to work continuously towards better governance (Gisselquist, 2012). However, to this point of view Adesida (2001), argued that governance in many African countries is still far from "good" because the systems are not as open as they should be. Additionally, most governments are unable to satisfy the most basic needs of their people; accountability and transparency are low, and many people are unable to participate effectively in the governance process.

In sum, the preceding paragraphs noted the need to emphasize good governance. However, apart from the theories in literature the "good governance" agenda has not been substantially treated in Ethiopia. In theory, good governance requires a participatory, accountable, transparent, and responsive system in the local government. However, research on assessing the practice of good governance principles at the local government level is not substantial and these issues have not been empirically examined and assessed in Bonga town. As a result, this research is a useful addition in filling this knowledge gap around assessing the empirical practice of good governance in local government and its impeding variables.

\section{STATEMENT OF THE PROBLEM}

According to UNDP cited in Gisselquist(2012), 'Good governance refers to governing systems which are capable, responsive, inclusive, and transparent. All countries, developed and developing, need to work continuously towards better governance'. In line with this international concern, the GOE has emphasized and started working to realize good governance at all government levels. Though the Ethiopian government is committed to realizing good governance at all levels, the literature reveals that research on good governance is lacking in municipal administrations. Tegene and Kassahun (2007,p: 55) pointed that research on issues such as accountability of service providers to users, representation and participation of users in the planning and decision-making process, and structures for participation and representation are almost lacking.

Moreover, substantial research has not been done regarding the practice of good governance principles in Ethiopia, and research on good governance in local government is also limited. Particularly there is no research found which has been done in BTA, despite the unreserved effort made by the researchers in searching out researches made in the area.

As the researchers experienced, in Bonga Town Administration (BTA) there is widespread public dissatisfaction and outcry regarding the absence of good governance. Mainly the dissatisfactions are associated with the lack of accountability and transparency of the town administration. Often common public grievances were observed on administrative accountability and transparency, unresponsiveness of local leaders, very low interaction between people and their local representatives, poor municipal service provision (pure water supply and refuse collection service), and access to information. Besides, there is pervasive corruption and high rent-seeking behavior among public servants and local government representatives. People reported that court decisions are subject to corruption and there is also delay in court trials. In line with this, though, public participation is critical for the development 
and realization of good governance, the research has revealed that in Bonga Town Administration public participation lacks luster. People reported as they don't prioritize and decide on their shared problems. Weak political leadership, lack of skilled public servants in service sectors, and absence of integrity among public officials were figured out as daunting challenges of good governance in the town.

\section{Research Questions}

- What are the views of the people regarding the practice of good governance (accountability and transparency, participation, rule of law, and control of corruption) in Bonga Town Administration?

- What is the status of municipal service provision (pure water supply and refuse collection) in Bonga Town Administration?

- What are the major challenges of good governance in Bonga Town Administration?

- What could be the possible and appropriate solution that will help in promoting good governance in Bonga Town Administration?

\section{REVIEW OF RELATED LITERATURE}

\section{The Concept of Governance}

There are different views on the good governance agenda among proponents and opponents of the idea. Proponents of good governance see it as a worthy goal not only in and of itself but also as a means through which to impact a variety of other outcomes, particularly economic growth and development (Gisselquist, 2012). Whereas, the opponents on the other side argue that the use of governance criteria in the allocation of foreign aid effectively introduces political conditionality and imposes Western liberal models of democracy (Ibid). Opposed to the argument there is a widespread consensus that good governance is a necessary ingredient of sustainable development. Owing to this, nations in the world including Ethiopia, regardless of their political ideology, economic development and other factors are striving to ensure good governance.

Despite the good governance debate, the definition of 'governance' itself remains uncertain and doubtful. There is no one single definition of governance; instead there exist several different definitions given by different organizations and scholars. According to Gisselquist(2012), not only do definitions vary across organizations; they also vary within organizations. For example, Gisselquist(2012) has referred to various definitions used by the WB at different times. Some of those definitions used by WB include: 'the exercise of political power to manage a nation's affairs', 'how public officials and institutions acquire and exercise the authority to shape public policy and provide public goods and services' and 'the rule of the rulers, typically within a given set of rules' (Gisselquist, 2012: 3) are some. However, there is a definition that has been used widely. UNDP (2007) has defined governance as: 
'...the system of values, policies, and institutions by which a society manages its economic, political, and social affairs through interactions within and among the state, civil society, and private sector. It is the way a society organizes itself to make and implement decisions-achieving mutual understanding, agreement, and action. It comprises the mechanisms and processes for citizens and groups to articulate their interests mediate their differences and exercise their legal rights and obligations. It is the rules, institutions, and practices that set limits and provide incentives for individuals, organizations, and firms. Governance including its social, political, and economic dimensions operates at every level of human enterprise, be it the household, village, municipality, nation, region, or globe (UNDP, 2007).

According to Gisselquist (2012), regardless of differences in language, most definitions of governance share three common defining elements such as (1) governance is a process (2) power exercised by actors, and (3) the management of collective affairs. Therefore minimally governance can be understood as the process or the manner through which power or authority is exercised by actors to manage the collective affairs of a community, society, and/ or nations at large. Moreover, according to Gisselquist many definitions of governance also include additional elements like (1) the core objectives met by effective governance (2) the principles, values, or norms that should be upheld in the process of governing, and (3) the specific institutions that well-governed countries should have. Furthermore, the process of governance involves various stakeholders or actors, government agencies, elected officials, hereditary rulers, religious leaders, judiciary authority, and the public (Ibid).

\section{Definition and Components of Good Governance}

It is widely accepted that "good governance" is a necessary condition to sustain economic development and ensure the prosperity of the country. According to UNDP, 'Good governance refers to governing systems which are capable, responsive, inclusive, and transparent. All countries, developed and developing, need to work continuously towards better governance (Gisselquist, 2012).

Accountability and Transparency: Accountability and transparency are critical components and key requirements of good governance. According to Tiwari(2004), good governance implies accountability to the citizens of a democratic polity and their involvement in decision making, implementation, and evaluation of projects, programs, and public policies. On the other side transparency makes sure that, people know exactly what is going and the rationale of the decisions taken by the government, or its functionaries at different levels. AfDB (1999) broadly defined transparency as public access to knowledge of the policies and strategies of government.

Responsiveness. Responsiveness is also one of the key components of good governance which urges the government to serve the public within a reasonable timeframe. Rodden and 
Wibbels(2012), noted that responsiveness and accountability have come to be seen as crucial ingredients of good governance. This is because good governance requires that institutions and processes try to serve all stakeholders within a reasonable timeframe.

Participation. Participation is defined as a process whereby stakeholders exercise influence over public policy decisions and share control over resources and institutions that affect their lives, thereby providing a check on the actions of government (AfDB, 1999). In the governance context, participation targets the empowerment of citizens and the interaction between civil societies, actors, and actions. In general, it is about a situation in which all citizens and private institutions can participate in their governance, generate a legitimate claim, and monitoring government policies and actions (Ibid).

Combating Corruption. Corruption is defined as the misappropriation of public assets or public office/trust for private gains. Concreting this definition cited in Lengseth (1999) WB and Transparency International (TI) defined corruption as "the misuse of public office for private gain." As such, it involves the improper and unlawful behavior of public-service officials, both politicians and civil servants, whose positions create opportunities for the diversion of money and assets from the government to them and their accomplices.

Rule of Law. The Secretary-General of UN (2013) cited in Nwekeaku(2014)defines the rule of law as a principle of governance in which all persons, institutions and entities, public and private, including the State itself, are accountable to laws that are publicly promulgated, equally enforced and independently adjudicated, and which are consistent with international human rights norms and standards. It requires as well measures to ensure adherence to the principles of supremacy of the law, equality before the law, accountability to the law, fairness in the application of the law, separation of powers, participation in decision-making, legal certainty, avoidance of arbitrariness, and procedural and legal transparency.

\section{ANALYTICAL FRAMEWORK}

Good governance is a good idea. We would all be better off, and citizens of many developing countries would be much better off if public life were conducted within institutions that were fair, judicious, transparent, accountable, participatory, responsive, well-managed, and efficient (Grindle, 2007).

The good governance agenda is the most debated concept in the world which is concerned with ensuring the quality of life for people. Even it is considered as one of the important factors for the eradication of poverty and sustaining the prosperity of a particular nation. The Global Campaign on Urban Governance definition of "good governance" constitutes elements like access to safe water, sanitation service, and a clean environment which are necessary conditions to make life better in urban areas. In Ethiopia also, these services are expected to be rendered by municipalities/local governments in the context of decentralization. As the researchers learned from literature that good governance has numerous components among which transparency and accountability are key attributes. 
Though good governance has many elements, the practice of good governance in BTA has been assessed referring to accountability and transparency, rule of law, control of corruption, and participation. Besides municipal service provisions like pure water supply and dry waste collection were also assessed to examine citizen's access to these basic services. The table below shows components of good governance selected for the research and indicators which are measured in assessing the practice of the principles.

Table 1: Indicator framework of good governance principles

\begin{tabular}{|l|l|}
\hline \multicolumn{2}{|c|}{ Good Governance } \\
\hline Components & Indicators \\
transparency & $\begin{array}{l}\text {-public access to information (access to knowledge of the policies and } \\
\text { strategies of government) } \\
\text {-timely information on economic, financial \& market conditions } \\
\text {-openness in public dealings } \\
\text {-right to information relating to service delivery process } \\
\text {-public engagement in decision making (eg. On areas of budgeting) } \\
\text {-annual performance report (making public accounts verifiable) } \\
\text {-compliant management }\end{array}$ \\
\hline Participation & $\begin{array}{l}\text {-stakeholders exercise influence over public policy decisions } \\
\text {-empowerment of citizens } \\
\text {-the interaction between government and citizen } \\
\text {-citizens are engaged in common public affairs at a variety of times } \\
\text { throughout the year } \\
\text {-opportunity to take part in the conduct of public affairs } \\
\text {-governance situation in which all citizens and private institutions can } \\
\text { participate in their governance }\end{array}$ \\
\hline Corruption & $\begin{array}{l}\text {-perception of corruption, stakeholders effort in containing corruption } \\
\text {-impartial enforcement of laws, access to justice }\end{array}$ \\
\hline & -access to refuse collection service \\
\hline
\end{tabular}




\section{METHODS}

\section{Research Design}

The research followed descriptive survey design which is cross-sectional in its approach. According to Leedy \& Ormrod (2001) cited in Idowu, Ifedayo \& Idowu (2020) descriptive survey design helps the researchers to gather data from a cross-section of the target population about an existing phenomenon. According to Singh(2006), the cross-sectional approach is concerned with information about any aspect of the phenomenon in the existing situation. According to Kumar(1999), cross-sectional studies, also known as one-shot or status studies, are the most commonly used design in social science. Since this research aimed to assess the ongoing practice of good governance and its challenges, descriptive research type had been used.

Both quantitative and qualitative data have been collected. The quantitative data collected through a questionnaire which was employed to the residents of the town. The qualitative information was gathered from local authorities, Municipal Councilors, and civil servants by structured interviews and focus group discussion (FGD).

\section{Population}

According to Marczyk, Dematteo \& Festinge(2005), "population" is all individuals of interest to the researchers. As a result, the target population of this study which the researchers are interested in was people living in BTA.

\section{Research Participants, Sampling Techniques and Procedure}

The participants of the study were those who have been selected based on the non-probability sampling technique. Purposive and convenience sampling techniques were utilized in this research. It is noted in Dawson (2002), 'purposive samples are used if description rather than generalization is the goal'. As a result the researchers purposefully selected Bonga town as the study site.

To get holistic information about the practice and challenges of good governance in BTA, the researchers have gathered data from the people (town residents), and local authorities of the town administration, municipal councilors, and Civil servants. Thus, key informants from the town administration were purposefully selected by using the criterion sampling technique for interviews and FGD.

In Bonga town, there are three Kebeles (K1, K2, and K3) and they all are purposefully taken, thereafter, respondents were selected through convenience sampling technique. The reasons for the use of convenience sampling were time and budget constraints and also though, there was the total number of households for each kebele in the town municipal council, there was no list of population. In addition to these respondents, willingness was also considered. According to the definition of Dornyei (2007) cited in Farrokhi(2012), Convenience sampling is a kind of non-probability or nonrandom sampling in which members of the target population, are selected for the study if they meet certain practical criteria, such as geographical proximity, availability at a certain time, easy accessibility, or the willingness to volunteer. Based on these 
determining factors approximately $1 \%$ or a total of 179 available households were interviewed from the three kebeles of the town.

Table 2: Sample frame

\begin{tabular}{|l|l|l|}
\hline $\begin{array}{l}\text { Number of } \\
\text { Kebele }\end{array}$ & Name of kebele & Sample households \\
\hline 1 & MeskelAdebabay & 79 \\
\hline 2 & MhalKetema & 40 \\
\hline 3 & ShetaKenteri & 60 \\
\hline Total & & 179 \\
\hline
\end{tabular}

\section{Instruments}

Questionnaire. The questionnaire was mainly designed in the form of a closed-ended questionnaire with some open-ended questions. It was translated into Amharic and administered with the help of data collectors. The utilized questionnaire has been categorized into six parts, the first part is about socio-demographic characteristics of the respondents constituted 3 questions and the questions are targeted at the personal details of the participants. The second part constituted 8 questions that explored the accountability and transparency issues in the town administration. The third part dealt with the general public participation and trends of participation, perception, and experience of participation were raised and it constituted 8 questions. Part four dealt with prevalence of rule of laws and public access to justice and constituted 4 questions. Part five was about control of corruption and public perception regarding the prevalence of corruption in the town administration and kebele administration and it constituted 5 questions. The final part, part six comprised a total of 2 questions and dealt with municipal service provision particularly pure water supply and refuse collection services.

To make certain the validity and reliability of the instrument the researchers have conducted a pilot test on respondents who are not part of the research sample. Thus, the geared up instrument had been given to peers and senior academicians for comments and suggestions, and then based on the feedback and pilot testing; the instrument was re-assessed intending to ascertain its validity and reliability.

Interview. The structured interview has been employed, this is because, as referred by Kumar (1999), a structured interview is advantageous in that it provides uniform information and requires fewer interviewing skills than does unstructured interviewing. As a result, an interview schedule had been prepared in an appropriate sequence and it was administered accordingly.

Focus Group Discussion (FGD). FGD was employed to substantiate data gathered through questionnaires and interviews. According to Dawson (2002), Focus Group Discussion (FGD) may 
be called a discussion group or group interview. In FGD a limited number of people are asked to come together in a group to discuss certain issues. The FGD theme was organized in a way that addresses issues that were not addressed through questionnaires and interviews. The FGD also addressed the same issues with the questionnaire and interview intending to get detailed data on points that need further information. In the group discussion, the following themes were encompassed; discussants observation on the practice of good governance and local government's activity in promoting good governance, trends of public participation, corruption, public service delivery, and possible suggestions to remedy the problem. The FGD was held in two groups. Each group constituted 8 discussants. The first group constituted discussants from the women's affairs office, municipal council, youth association, and kebele leaders. Participants of the second group were municipal workers, traders, civil servants, and local elders. In each group 1:30 to 2 hours long time was spent. The discussion was led by a facilitator who was in charge of introducing the topic, asking specific questions, ensuring that no person is dominating the discussion, and controlling deviations from the discussion. Holding the discussion taperecord was used.

\section{Data Analysis Procedures and Interpretation}

Primarily the collected data have been screened intending to ascertain its accuracy and completeness. In this regard the researchers were carefully checked out whether the required responses are given appropriately, are they complete, and necessary information has been included or not. After screening the collected data the next step was constructing a database. According to Marczyk, Dematteo, and Festinge (2005), once data are screened and all corrections are made, the data should be entered into a well-structured database. This helped the researchers to determine which variable need to be entered and how it will be ordered. In line with this activity, specific codes were given for each variable before proceeding to the next step. Having done these all tasks, the data had been entered into a database. For this particular research, SPSS V20 (Statistical package for social science) was utilized to process the data and while feeding the database the researchers have performed it twice.

Considering the type of research and the research questions, a descriptive statistic was employed to statistically analyze data obtained by questionnaire. The chief objective of descriptive statistics is to accurately describe distributions of certain variables within a specific data set (Marczyk, Dematteo, and Festinge, 2005). Therefore based on descriptive statistics, data were analyzed using frequency distribution in percentile and presented by using tables, graphs, and pi-chart. For analyzing information obtained from open-ended questionnaires and interviews, the content analysis technique was employed and analyzed in a way that substantiates the data obtained from the questionnaire. 


\section{RESULTS AND DISCUSSION}

The Socio-Demographic Characteristics of Respondents

Table 3: Percent Distribution of Respondents by Gender, Age, and Educational Background

\begin{tabular}{|c|c|c|c|c|c|c|c|c|}
\hline $\begin{array}{l}\text { Gender of } \\
\text { Respondent } \\
\text { S }\end{array}$ & $F$ & $\%$ & $\begin{array}{l}\text { Age } \\
\text { categ } \\
\text { ory }\end{array}$ & $F$ & $\%$ & $\begin{array}{l}\text { Educational } \\
\text { Background }\end{array}$ & $F$ & $\%$ \\
\hline Male & 94 & 52.5 & $21-30$ & 44 & $24.58 \%$ & $1-8$ & 11 & 6.1 \\
\hline Female & 85 & 47.5 & $31-40$ & 62 & $34.6 \%$ & Grade $9-12$ & 17 & 9.5 \\
\hline Total & $\begin{array}{l}17 \\
9\end{array}$ & 100 & $41-50$ & 58 & $32.4 \%$ & Certificate & 28 & 15.6 \\
\hline$>51$ & & & & 15 & 8.38 & Diploma & 53 & 29.6 \\
\hline Total & & & & 179 & $100 \%$ & Bachelor Degree & 58 & 32.4 \\
\hline Above & & & & & & & 12 & 6.7 \\
\hline Total & & & & & & & 179 & 100 \\
\hline
\end{tabular}

Source: Survey result, 2019.

Regarding the gender of respondents, table 3 above depicted that 94 (52.5\%) males and 85 (47.5\%) females participated. In terms of age group, the majority of respondents about 62 (34.6\%) were between the age of 31-40, followed by 58 (32.4\%) between the age of 41-50, 44 (24.58\%) between the age of 21-30 and 15 (8.38\%) were above 51. Concerning educational background, around 58 (32.4\%) and 53 (29.6\%) of research participants were degree and diploma holders respectively. The remaining 28 (15.6\%), $17(9.5 \%), 12(6.7 \%)$ and $11(6.1 \%)$ were certificate, Grade $9-12$, above degree, and grade 1-8 respectively.

\section{Public Views on Transparency and Accountability in BTA}

The data in table 4 above suggest that laws and policies are not applied transparently and predictably. As seen in the table, the majority of respondents disagreed with the view that laws and policies are applied transparently and predictably. This means, 69 (38.5\%) and 50 (27.9\%) of male and female respondents were in the categories of disagree and strongly disagree respectively. However, about 45 (25.1\%) of male and female respondents agreed that laws and policies are applied transparently and predictably. The remaining 15 (8.4\%) of male and female 
respondents were uncertain of the view that laws and policies are applied transparently and predictably.

Table 4: Public Views regarding the openness of laws, policies and administrative decisions in BTA

\begin{tabular}{|c|c|c|c|c|c|c|c|c|c|c|c|}
\hline \multirow[t]{3}{*}{ Items } & \multirow{3}{*}{$\begin{array}{l}\text { Respo } \\
\text { ndent } \\
\mathrm{s}\end{array}$} & & & & & & & & & \multirow{2}{*}{\multicolumn{2}{|c|}{ Total }} \\
\hline & & \multicolumn{2}{|c|}{ Agree } & \multicolumn{2}{|c|}{$\begin{array}{c}\text { Uncertai } \\
\mathrm{n}\end{array}$} & \multicolumn{2}{|c|}{ Disagree } & \multicolumn{2}{|c|}{\begin{tabular}{|l} 
Strongly \\
Disagree
\end{tabular}} & & \\
\hline & & $\mathrm{F}$ & $\%$ & $F$ & $\%$ & $F$ & $\%$ & $\mathrm{~F}$ & $\%$ & $F$ & $\%$ \\
\hline \multirow{3}{*}{$\begin{array}{l}\text { Laws and policies are } \\
\text { applied in a } \\
\text { transparent \& } \\
\text { predictable manner }\end{array}$} & Male & 17 & $9.5 \%$ & 6 & $3.4 \%$ & 39 & $21.8 \%$ & 32 & $17.9 \%$ & 94 & $52.5 \%$ \\
\hline & Femal & 28 & $15.6 \%$ & 9 & $5.0 \%$ & 30 & $16.8 \%$ & 18 & $10.1 \%$ & 85 & $47.5 \%$ \\
\hline & Total & 45 & $25.1 \%$ & 15 & $8.4 \%$ & 69 & $38.5 \%$ & 50 & $27.9 \%$ & $\begin{array}{r}17 \\
9\end{array}$ & $100.0 \%$ \\
\hline \multirow{3}{*}{$\begin{array}{l}\text { Administrative } \\
\text { decisions are } \\
\text { transparent to the } \\
\text { people }\end{array}$} & Male & 13 & $7.3 \%$ & 6 & $3.4 \%$ & 40 & $22.3 \%$ & 35 & $19.6 \%$ & 94 & $52.5 \%$ \\
\hline & Femal & 24 & $13.4 \%$ & 15 & $8.4 \%$ & 32 & $17.9 \%$ & 14 & $7.8 \%$ & 85 & $47.5 \%$ \\
\hline & Total & 37 & $20.7 \%$ & 21 & $11.7 \%$ & 72 & $40.2 \%$ & 49 & $27.4 \%$ & $\begin{array}{r}17 \\
9\end{array}$ & $100.0 \%$ \\
\hline
\end{tabular}

Source: Survey result, 2019

Regarding administrative decisions about 40 (22.3\%) and 35 (19.6\%) of male respondents were responded to disagree and strongly disagree with the view that administrative decisions are transparent to the people. Similarly, around $32(17.6 \%)$ and $14(7.8 \%)$ of female respondents were also replied disagree and strongly disagree. But 24 (13.4\%) females were agreed that administrative decisions are transparent compared to 13 (7.3\%) of male respondents. Therefore, research result in the above table reveals that transparency and accountability are found to be low in the application of laws and policies, and in making administrative decisions. However, contrary to the empirical research result evidenced above, UN-HABITAT, (2002) argue transparency and accountability as major pillars of good governance and suggested laws and public policies be applied transparently and predictably. 


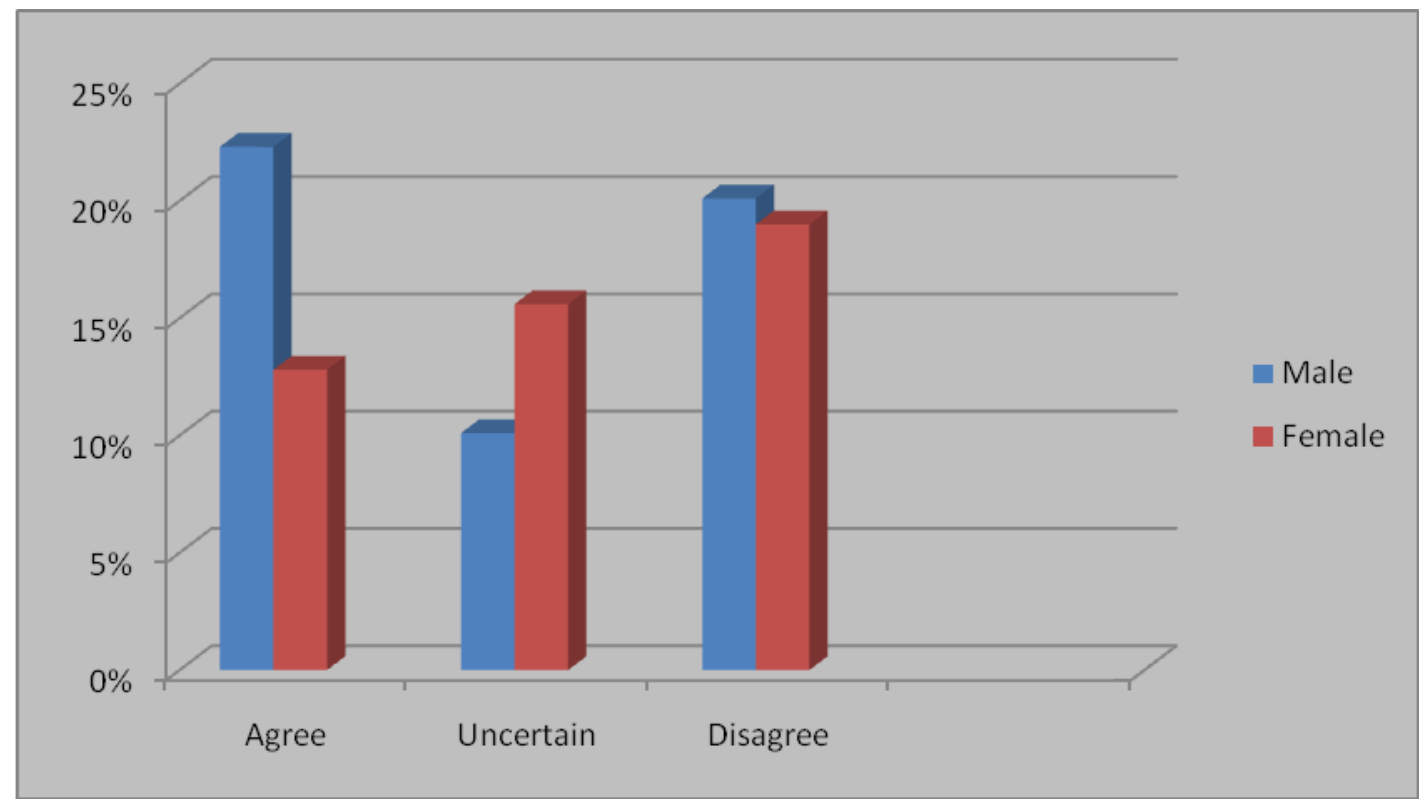

Figure 1: Accessibility of public office information to service users Source: Survey result, 2019

The data in figure 1 tell that information is relatively less accessible to service users. About 36 (20.1\%) of male and 34 (19\%) of female respondents disagreed. This means 70 (39.1\%) of male and female respondents were in disagreement with the view that public offices do provide information to service users. Whereas, $40(22.3 \%)$ of male and $23(12.8 \%)$ of female respondents experienced that public office information is accessible to the people. The remaining $46(25.7 \%)$ of sample respondents were reported uncertain. As we understood from the data in the above figure, accessibility of public office information to service users is found to be minimal in Bonga Town Administration. This is contrary to the recommendations given by the literature. As it is argued by MoFED (2009), local governments should disseminate information about where to go/whom to contact in case of questions or problems with a service.

The data in the above Table 5 enlightens the low level of open consultation between local government and the town people on the municipal budget. About 65 (36.3\%) and 28 (15.6\%) of male and female respondents were reported as disagree and strongly disagree with the view that the local government holds open consultation about the municipal budget. Whereas, 46 (25.7\%) of male and female respondents reported that the local government holds an open consultation with the people regarding the municipal budget. The remaining $40(22.3 \%)$ of sample respondents were responded uncertain. Thus, according to the data, it can be inferred that the local government has a low level of consultation with its people concerning various affairs of the community. 
Table 5: Public view regarding municipal budget consultation and publicity of budget

\begin{tabular}{|c|c|c|c|c|c|c|c|c|c|c|c|}
\hline \multirow[t]{3}{*}{ Items } & \multirow{3}{*}{$\begin{array}{l}\text { Respo } \\
\text { ndent } \\
\text { S }\end{array}$} & & & & & & & & & \multirow{2}{*}{\multicolumn{2}{|c|}{ Total }} \\
\hline & & \multicolumn{2}{|c|}{ Agree } & \multicolumn{2}{|c|}{$\begin{array}{c}\text { Uncertai } \\
\mathrm{n}\end{array}$} & \multicolumn{2}{|c|}{ Disagree } & \multicolumn{2}{|c|}{$\begin{array}{l}\text { Strongly } \\
\text { Disagree }\end{array}$} & & \\
\hline & & $F$ & $\%$ & $\mathrm{~F}$ & $\%$ & $F$ & $\%$ & $F$ & $\%$ & $\mathrm{~F}$ & $\%$ \\
\hline \multirow{3}{*}{$\begin{array}{l}\text { Does your local } \\
\text { government hold an } \\
\text { open consultation } \\
\text { regarding municipal } \\
\text { budget? }\end{array}$} & Male & 28 & $15.6 \%$ & 16 & $8.9 \%$ & 37 & $20.7 \%$ & 13 & $7.3 \%$ & 94 & $52.5 \%$ \\
\hline & Femal & 18 & $10.1 \%$ & 24 & $13.4 \%$ & 28 & $15.6 \%$ & 15 & $8.4 \%$ & 85 & $47.5 \%$ \\
\hline & Total & 46 & $25.7 \%$ & 40 & $22.3 \%$ & 65 & $36.3 \%$ & 28 & $15.6 \%$ & $\begin{array}{r}17 \\
0\end{array}$ & $100.0 \%$ \\
\hline \multirow{3}{*}{$\begin{array}{l}\text { The budget proposal is } \\
\text { posted in a visible } \\
\text { place to people? }\end{array}$} & Male & 18 & $10.1 \%$ & 37 & $20.7 \%$ & 23 & $12.8 \%$ & 16 & $8.9 \%$ & 94 & $52.5 \%$ \\
\hline & Femal & 21 & $11.7 \%$ & 22 & $12.3 \%$ & 32 & $17.9 \%$ & 10 & $5.6 \%$ & 85 & $47.5 \%$ \\
\hline & Total & 39 & $21.8 \%$ & 59 & $33.0 \%$ & 55 & $30.7 \%$ & 26 & $14.5 \%$ & $\begin{array}{r}17 \\
9\end{array}$ & $100.0 \%$ \\
\hline
\end{tabular}

Source: Survey result, 2019

On the question of making known the budget proposal of the town, a considerable number of respondents affirmed that the budget proposal is not posted in a place visible to the town people. This means about 55 (30.7\%) and 26 (14.5\%) of respondents were of the view that budget proposal is not publicly known. But, around 39 (21.8\%) of male and female sample respondents agreed to the view that budget proposal is posted in a place visible to the people. The remaining 59 (33\%) of respondents were reported uncertain. Therefore, the study revealed that the budget proposal is not announced to the people publicly affecting transparency in local government which is against the requirement set by the Ministry of Finance and Economic Development of Ethiopia. MoFED (2009) argued that woredas, urban administrations, and kebeles are required to post information about budget allocation outside woreda and kebele offices, schools, health posts, market places, or in other places where people can see it. 


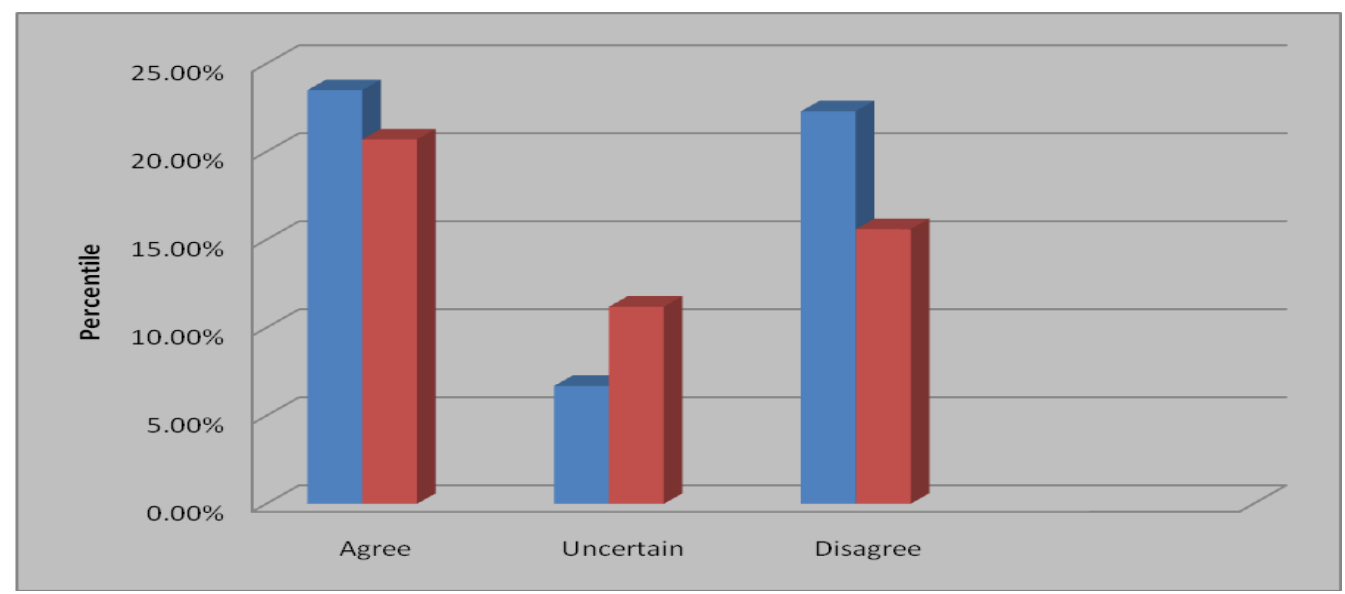

Figure 2: Annual performance reports are announced to the people

Source: Survey result, 2019

Concerning annual performance reports, about 79 (44.1\%) of respondents were in agreement that, annual performance reports are announced to the people. Whereas, $68(38 \%)$ of male and female respondents were reported as disagreed with the view that annual performance reports are announced to the people. The remaining $32(17.9 \%)$ respondents responded uncertain. Therefore according to the data on the above figure, there is a relatively positive experience in announcing an annual performance report for the people. But this alone can't be good enough, because citizens without being involved initially in the budget consultation and informed about the amount of budget proposal can't hold their representatives accountable for their performance. This is because as pointed by McGee \& Gaventa (2010), transparency is a prerequisite for accountability and there is also an assumption that transparency produces accountability. Hence, it is difficult to enforce accountability without transparency.

Table 6: Respondents' experience with the public compliant office of the town?

\begin{tabular}{|c|c|c|c|c|c|c|}
\hline \multirow[t]{3}{*}{ Respondents } & \multicolumn{4}{|c|}{$\begin{array}{c}\text { Have you ever gone to a public complaint } \\
\text { office to voice your complaint in the past } 12 \\
\text { months? }\end{array}$} & \multicolumn{2}{|c|}{ Total } \\
\hline & \multicolumn{2}{|c|}{ Yes } & \multicolumn{2}{|c|}{ No } & & \\
\hline & $\mathrm{F}$ & $\%$ & $\mathrm{~F}$ & $\%$ & $\mathrm{~F}$ & $\%$ \\
\hline Male & 31 & $17.3 \%$ & 63 & $35.2 \%$ & 94 & $52.5 \%$ \\
\hline Female & 18 & $10.1 \%$ & 67 & $37.4 \%$ & 85 & $47.5 \%$ \\
\hline Total & 49 & $27.4 \%$ & 130 & $72.6 \%$ & 179 & $100 \%$ \\
\hline
\end{tabular}

Source: Survey result, 2019 
According to the data in the above table 6 , about $31(17.3 \%)$ of male and $18(10.1 \%)$ of female respondents replied that they have gone to a public compliant handling office and got service. This means that around $49(27.4 \%)$ of male and female respondents were got service from the office. The majority of respondents $63(35.2 \%)$ of male and 67 (37.4\%) of female respondents have not gone to compliant handling office.

Table 7: Public Satisfaction regarding compliant handling office's service provision

\begin{tabular}{|c|c|c|c|c|c|c|}
\hline \multirow[t]{3}{*}{ Respondents } & \multicolumn{4}{|c|}{$\begin{array}{c}\text { If "Yes" how satisfied are you } \\
\text { with the service you got from the } \\
\text { office? }\end{array}$} & \multirow{2}{*}{\multicolumn{2}{|c|}{ Total }} \\
\hline & \multicolumn{2}{|c|}{ Dissatisfied } & \multicolumn{2}{|c|}{$\begin{array}{c}\text { Very } \\
\text { Dissatisfied }\end{array}$} & & \\
\hline & $\mathrm{F}$ & $\%$ & $\mathrm{~F}$ & $\%$ & $\mathrm{~F}$ & $\%$ \\
\hline Male & 22 & $44.9 \%$ & 9 & $18.4 \%$ & 31 & $63.3 \%$ \\
\hline Female & 10 & $20.4 \%$ & 8 & $16.3 \%$ & 18 & $36.7 \%$ \\
\hline Total & 32 & $65.3 \%$ & 17 & $34.7 \%$ & 49 & $100 \%$ \\
\hline
\end{tabular}

Source: Survey result, 2019

The respondents who have gone to the compliant office were also asked about their view of satisfaction with the service they got from the office. All of the respondents replied that they were dissatisfied with the provision of service by the compliant office. This means 32 (65.3\%) of male and female respondents were dissatisfied with the service they have got from the compliant handling office in their town. The remaining 17 (34.7\%) male and female respondents also replied as they were very dissatisfied with the service which negatively contributes to good governance practice. According to MoFED (2009), the perceived responsiveness to complaints highly correlates with satisfaction level. However, respondents of the study had been dissatisfied with the service they got from the compliant office.

\section{Public Participation in the Town}

As can be seen from Table 8 above, a significant number of respondents from all kebele disagreed with the view that authorities in the town administration encourage the people to make participate in development planning and other activities of the town. This means, around $87(48.6 \%)$ and 43 (24\%) of all kebele respondents replied disagree and strongly disagree respectively. However, around 42 (23.5\%) of respondents agreed and the remaining 7 (3.9\%) of respondents were uncertain to the view that authorities in the town administration encourage the people to make participate in development planning and other activities of the town. 
Therefore, according to the study, the local government seems less participatory; despite participatory governance is one of the key components of good governance.

Table 8: public view regarding the town administration representatives, in encouraging the people to take part in public affairs of the town

\begin{tabular}{|c|c|c|c|c|c|c|c|c|c|c|c|}
\hline \multirow[t]{3}{*}{ Items } & \multirow{3}{*}{$\begin{array}{l}\text { Respond } \\
\text { ents }\end{array}$} & & & & & & & & & \multirow{2}{*}{\multicolumn{2}{|c|}{ Total }} \\
\hline & & \multicolumn{2}{|c|}{ Agree } & \multicolumn{2}{|c|}{$\begin{array}{c}\text { Uncertai } \\
n\end{array}$} & \multicolumn{2}{|c|}{ Disagree } & \multicolumn{2}{|c|}{$\begin{array}{l}\text { Strongly } \\
\text { Disagree }\end{array}$} & & \\
\hline & & $\mathrm{F}$ & $\%$ & $F$ & $\%$ & $\mathrm{~F}$ & $\%$ & $F$ & $\%$ & $F$ & $\%$ \\
\hline \multirow{4}{*}{$\begin{array}{l}\text { Do authorities in your } \\
\text { town administration } \\
\text { encourage you to } \\
\text { make participate in } \\
\text { development planning } \\
\text { and other activities? }\end{array}$} & Kebele 1 & 12 & $6.7 \%$ & 4 & $2.2 \%$ & 44 & $24.6 \%$ & 19 & $10.6 \%$ & 79 & $44.1 \%$ \\
\hline & Kebele 2 & 13 & $7.3 \%$ & 2 & $1.1 \%$ & 20 & $11.2 \%$ & 5 & $2.8 \%$ & 40 & $22.3 \%$ \\
\hline & Kebele 3 & 17 & $9.5 \%$ & 1 & $0.6 \%$ & 23 & $12.8 \%$ & 19 & $10.6 \%$ & 60 & $33.5 \%$ \\
\hline & Total & 42 & $23.5 \%$ & 7 & $3.9 \%$ & 87 & $48.6 \%$ & 43 & $24.0 \%$ & 179 & $100 \%$ \\
\hline \multirow{4}{*}{$\begin{array}{l}\text { Does town } \\
\text { administration hold a } \\
\text { public hearing to } \\
\text { identify and prioritize } \\
\text { public problems? }\end{array}$} & Kebele 1 & 10 & $5.6 \%$ & 3 & $1.7 \%$ & 44 & $24.6 \%$ & 22 & $12.3 \%$ & 79 & $44.1 \%$ \\
\hline & Kebele 2 & 5 & $2.8 \%$ & 4 & $2.2 \%$ & 9 & $5.0 \%$ & 22 & $12.3 \%$ & 40 & $\begin{array}{l}22.3 \\
\%\end{array}$ \\
\hline & Kebele 3 & 15 & $8.4 \%$ & 1 & $0.6 \%$ & 24 & $13.4 \%$ & 20 & $11.2 \%$ & 60 & $33.5 \%$ \\
\hline & Total & 30 & $16.8 \%$ & 8 & $4.5 \%$ & 77 & $43.0 \%$ & 64 & $35.8 \%$ & 179 & $100 \%$ \\
\hline \multirow{4}{*}{$\begin{array}{l}\text { The town } \\
\text { administration holds } \\
\text { public consultations } \\
\text { about service delivery }\end{array}$} & Kebele 1 & 10 & $5.6 \%$ & 7 & $3.9 \%$ & 33 & $18.4 \%$ & 29 & $16.2 \%$ & 79 & $44.1 \%$ \\
\hline & Kebele 2 & 5 & $2.8 \%$ & 2 & $1.1 \%$ & 15 & $8.4 \%$ & 18 & $10.1 \%$ & 40 & $22.3 \%$ \\
\hline & Kebele 3 & 9 & $5.0 \%$ & 1 & $0.6 \%$ & 30 & $16.8 \%$ & 20 & $11.2 \%$ & 60 & $33.5 \%$ \\
\hline & Total & 24 & $13.4 \%$ & 10 & $5.6 \%$ & 78 & $43.6 \%$ & 67 & $37.4 \%$ & 179 & $100 \%$ \\
\hline
\end{tabular}

Source: Survey result, 2019

Similarly, a majority of respondents of all kebele also disagreed with the view that the town administration holds public consultation to identify and prioritize public problems. This means, around 77 (43\%) and 64 (35.8\%) of respondents from all kebele responded disagree and strongly disagree respectively. The remaining $30(16.8 \%)$ and $8(4.5)$ of respondents responded agree and uncertain respectively to the view that the town administration holds public 
consultation to identify and prioritize public problems. The study also reveals that there is a low level of local government consultation with its people about service delivery in the town. About $78(43.6 \%)$ and 67 (37.4\%) of respondents from all kebele responded as disagree and strongly disagree with the view that the local government holds public consultations about service delivery. However, opposed to the study result literature argued that local governments need to put in place systems that allow them to improve services in the ways that most closely reflect the needs and priorities of citizens (MoFED, 2009). Unlike this, citizens have little say in service provision and prioritization of shared problems in Bonga Town.

Table 9: Citizens were asked to offer opinions on freedom of opinion expression

\begin{tabular}{|c|c|c|c|c|c|c|c|c|c|c|}
\hline \multirow[t]{3}{*}{$\begin{array}{l}\text { Responde } \\
\text { nts }\end{array}$} & \multicolumn{8}{|c|}{$\begin{array}{l}\text { In the town, citizens have the freedom to express their } \\
\text { opinion in public }\end{array}$} & \multirow{2}{*}{\multicolumn{2}{|c|}{ Total }} \\
\hline & \multicolumn{2}{|c|}{ Agree } & \multicolumn{2}{|c|}{ Uncertain } & \multicolumn{2}{|c|}{ Disagree } & \multicolumn{2}{|c|}{$\begin{array}{l}\text { Strongly } \\
\text { Disagree }\end{array}$} & & \\
\hline & $F$ & $\%$ & $\mathrm{~F}$ & $\%$ & $\mathrm{~F}$ & $\%$ & $\mathrm{~F}$ & $\%$ & $F$ & $\%$ \\
\hline Kebele 1 & 41 & $22.9 \%$ & 6 & $3.4 \%$ & 22 & $12.3 \%$ & 10 & $5.6 \%$ & 79 & $44.1 \%$ \\
\hline Kebele 2 & 24 & $13.4 \%$ & 1 & $0.6 \%$ & 14 & $7.8 \%$ & 1 & $0.6 \%$ & 40 & $22.3 \%$ \\
\hline Kebele 3 & 24 & $13.4 \%$ & 5 & $2.8 \%$ & 24 & $13.4 \%$ & 7 & $3.9 \%$ & 60 & $33.5 \%$ \\
\hline Total & 89 & $49.7 \%$ & 12 & $6.7 \%$ & 60 & $33.5 \%$ & 18 & $10.1 \%$ & 179 & $100 \%$ \\
\hline
\end{tabular}

Source: Survey result, 2019

The above Table 9 portrays that, around 89 (49.7\%) of respondents from all kebele were in agreement with the view that, citizens have the freedom to express their opinion publicly in the town. Around 60 (33.5\%) and 18 (10.1\%) of respondents responded as disagree and strongly disagree with the view that citizens have the freedom to express their opinion publicly in the town. Therefore, the finding enlightens that citizens have relative freedom in expressing their opinions in public.

As can be seen in Table 10, around 164 (91.6\%) of all respondents participated in electing the local leaders. Around 77 (43\%) of respondents who participated in the election were females as compared to $87(48.6 \%)$ male respondents. Whereas, the data in the same table depicted a low level of citizens' attendance in public meetings held in their local government in the past 12 months. Around 75 (41.9\%) of male and 57 (31.8\%) of female respondents responded 'No'. Therefore, 132 (73.7\%) of all respondents did not participate in public meetings of the local government in the past 12 months, which is contrary to the premises of participatory 
governance in which citizens are required to be engaged in public venues (common public affairs) at a variety of times throughout the year (McNuty, 2004).

Table 10: Citizens participation in local election and meeting attendance on various issues of the town

\begin{tabular}{|c|c|c|c|c|c|c|c|}
\hline \multirow[t]{3}{*}{ Items } & \multirow[t]{3}{*}{ Respondents } & & & & & \multirow{2}{*}{\multicolumn{2}{|c|}{ Total }} \\
\hline & & \multicolumn{2}{|c|}{ Yes } & \multicolumn{2}{|c|}{ No } & & \\
\hline & & $\mathrm{F}$ & $\%$ & $\mathrm{~F}$ & $\%$ & $\mathrm{~F}$ & $\%$ \\
\hline \multirow{3}{*}{$\begin{array}{l}\text { Have you ever participated in } \\
\text { electing your local leaders? }\end{array}$} & Male & 87 & $48.6 \%$ & 7 & $3.9 \%$ & 94 & $52.5 \%$ \\
\hline & Female & 77 & $43.0 \%$ & 8 & $4.5 \%$ & 85 & $47.5 \%$ \\
\hline & Total & 164 & $91.6 \%$ & 15 & $8.4 \%$ & 179 & $100.0 \%$ \\
\hline \multirow{3}{*}{$\begin{array}{l}\text { Have you attended a public } \\
\text { meeting/consultation in the past } \\
12 \text { months, regarding } \\
\text { development planning and other } \\
\text { common issues of the town? }\end{array}$} & Male & 19 & $10.6 \%$ & 75 & $\begin{array}{c}41.9 \\
\%\end{array}$ & 94 & $52.5 \%$ \\
\hline & Female & 28 & $15.6 \%$ & 57 & $\begin{array}{c}31.8 \\
\%\end{array}$ & 85 & $47.5 \%$ \\
\hline & Total & 47 & $26.3 \%$ & 132 & $\begin{array}{c}73.7 \\
\%\end{array}$ & 179 & $100 \%$ \\
\hline
\end{tabular}

Source: Survey result, 2019

The information obtained from key informants of the interview and participants of FGD also confirmed that females have more attendance than males in a public meeting held at kebele as well as town level. The interview result obtained from key informants also identified attitudinal factors contributing to less attendance of males in meetings and public consultations:

- Males consider attending a meeting as wasting time, thus they give priority to their dayto-day activities

- Considering meetings as valueless, they let women's to attend the meetings on behalf of them

In the open-ended question respondents who haven't attended public consultations or meetings in their locality in the past 12 months, were asked to mention the main reasons for their absence. Accordingly, the majority of respondents both male and female pointed the following reasons as the major variables affecting their attendance in meetings:

- Agendas always flow from top to down to the grass root people

- Most of the town agendas are predefined 
- Attending meeting has no value; this is because local leaders took suggestions and comments from gathered people during the meetings and they pledged to consider ideas coming from the people, however in practice received feedback from the people kept ignored without being considered.

- Similar issues frequently raised in public meeting and consultations

- Discriminating and discouraging those who speak the truth and try to expose wrongdoings

- Local authorities are less committed to encouraging the people to take part in public issues

Table 11: Citizens were asked to offer opinions about problems that affect active public participation in the town administration in general

\begin{tabular}{|c|c|c|c|c|c|c|}
\hline \multirow[t]{3}{*}{ Gender of respondents } & \multicolumn{4}{|c|}{$\begin{array}{l}\text { Do you think that there are problems that } \\
\text { affect active public participation in the } \\
\text { town? }\end{array}$} & \multirow{2}{*}{\multicolumn{2}{|c|}{ Total }} \\
\hline & \multicolumn{2}{|c|}{ Yes } & \multicolumn{2}{|c|}{ No } & & \\
\hline & $\mathrm{F}$ & $\%$ & $\mathrm{~F}$ & $\%$ & $F$ & $\%$ \\
\hline Male & 92 & $51.4 \%$ & 2 & $1.1 \%$ & 94 & $52.5 \%$ \\
\hline Female & 84 & $46.9 \%$ & 1 & $0.6 \%$ & 85 & $47.5 \%$ \\
\hline Total & 176 & $98.3 \%$ & 3 & $1.7 \%$ & 179 & $100 \%$ \\
\hline
\end{tabular}

Source: Survey result, 2019

The data in the above table 11 indicates the prevalence of problems affecting the active participation of the people in the town. Almost all male and female respondents affirmed that there are problems that affect the participation of people in the town. As can be seen in the table around $98.3 \%$ of male and female respondents responded 'yes' regarding the prevalence of problems deterring public participation. Through open-ended questions and FGD respondents were also asked to identify the problems affecting public participation. Based on this the following elements were identified as major challenges affecting the general participation of people in the town:

- Unresponsiveness of local government; due to this people are less interested to take part in public affairs

- Public officials and authorities are not keen enough in mobilizing the people for participation 
- People are not fully exercising their right to discussion and decision making on shared problems. Instead, local leaders let them accept what has been decided and do what is ordered by them.

- There is a gap between people and local authorities. Authorities are not close enough to the people.

- Poor public service delivery especially pure water supply, internal road building, refuse collection, etc... and specifically the public dissatisfaction related to these issues.

Table 12: Men and Women access to and influence on decision making in the town

\begin{tabular}{|c|c|c|c|c|c|c|c|c|}
\hline \multirow[t]{3}{*}{ Respondents } & \multicolumn{6}{|c|}{$\begin{array}{l}\text { Do you think that women and men have equal access } \\
\text { and influence on decision making in your locality? }\end{array}$} & \multirow{2}{*}{\multicolumn{2}{|c|}{ Total }} \\
\hline & \multicolumn{2}{|c|}{$\begin{array}{l}\text { No men have } \\
\text { more influence } \\
\text { and access }\end{array}$} & \multicolumn{2}{|c|}{$\begin{array}{c}\text { No women } \\
\text { have more } \\
\text { influence and } \\
\text { access }\end{array}$} & \multicolumn{2}{|c|}{$\begin{array}{c}\text { Yes men and } \\
\text { women have } \\
\text { equal access and } \\
\text { influence }\end{array}$} & & \\
\hline & $\mathrm{F}$ & $\%$ & $\mathrm{~F}$ & $\%$ & $\mathrm{~F}$ & $\%$ & $F$ & $\%$ \\
\hline Male & 39 & $21.8 \%$ & 3 & $1.7 \%$ & 52 & $29.1 \%$ & 94 & $52.5 \%$ \\
\hline Female & 25 & $14.0 \%$ & 5 & $2.8 \%$ & 55 & $30.7 \%$ & 85 & $47.5 \%$ \\
\hline Total & 64 & $35.8 \%$ & 8 & $4.5 \%$ & 107 & $59.8 \%$ & $\begin{array}{r}17 \\
9\end{array}$ & $100.0 \%$ \\
\hline
\end{tabular}

Source: Survey result, 2019

Concerning decision making in the town, the majority of respondents $52(29.1 \%)$ male and $55(30.7 \%)$ female respondents replied "yes" to the view that men and women have equal access and influence on decision making. This means, about 107 (59.8\%) of respondents believe that women and men have equal access and influence on decision making in the town. About $64(35.8 \%)$ of male and female respondents also believe that men have more access and influence on decision making. Therefore, it is possible to infer that, relatively women have equal access and influence with men in decision making. This is found to be a good experience, because women participation in every affair of state is strongly needed to ensure good governance and sustainable development. Adding to this point Aburaida, (2020) argued that, Sustainable development is achieved through equality between women and men in rights, opportunities, and responsibilities. 
Table 13: Proportion of women representatives in administrative councils of the town

\begin{tabular}{|l|l|l|l|}
\hline \multirow{2}{*}{ Kevel of administrative councils } & Gender & $\mathrm{N}$ & $\%$ \\
\hline \multirow{2}{*}{ K2 Council (Meskel Adebabay) } & Male & 107 & 53.5 \\
\cline { 2 - 4 } & Female & 93 & 46.5 \\
\cline { 2 - 4 } & Total & 200 & 100 \\
\hline \multirow{2}{*}{ K3 Council (Sheta Kenteri) } & Male & 107 & 53.5 \\
\cline { 2 - 4 } & Female & 93 & 46.5 \\
\cline { 2 - 4 } & Total & 200 & 100 \\
\hline \multirow{2}{*}{ BTA Council } & Male & 99 & 49.5 \\
\cline { 2 - 5 } & Female & 101 & 50.5 \\
\cline { 2 - 5 } & Total & 200 & 100 \\
\hline & Male & 32 & 62.75 \\
\cline { 2 - 4 } & Female & 19 & 37.25 \\
\cline { 2 - 4 } & Total & 51 & 100 \\
\hline
\end{tabular}

Source: BTA Council, 2019

According to the data in table 13 above, women councilors have a similar number in the first two kebele councils (K1 and K2). This means they took 93 (46.5\%) share of the total kebele council in each kebele, while the remaining 107 (53.5\%) of kebele council is occupied by men councilors. Whereas, in kebele 3 women councilors have equal proportion with men, around 101 (50.5\%) of the total councilors are women. In the case of a municipal council, women have less number as compared to men. Women councilors in the municipal council are 19 (37.5\%) as compared to 32 (62.75\%) of men councilors. In sum, as can be seen in table 21 , women have relatively good participation in kebele council than the municipal council.

\section{Public Perception Regarding Rule of Law and Access to Justice}

Figure 3 suggests that a significant number of male and female respondents had experience with the municipal court. Around 128 (71.5\%) of all respondents responded that they have experience with the municipal court directly or indirectly through their neighborhood. Only 51 (28.5\%) of respondents had no experience with the town court. Respondents who had experience with the town administration directly or indirectly through their neighborhood were asked to share opinions about court decisions, trial process, and perceptions on the subjectivity of court decisions to corruption. 


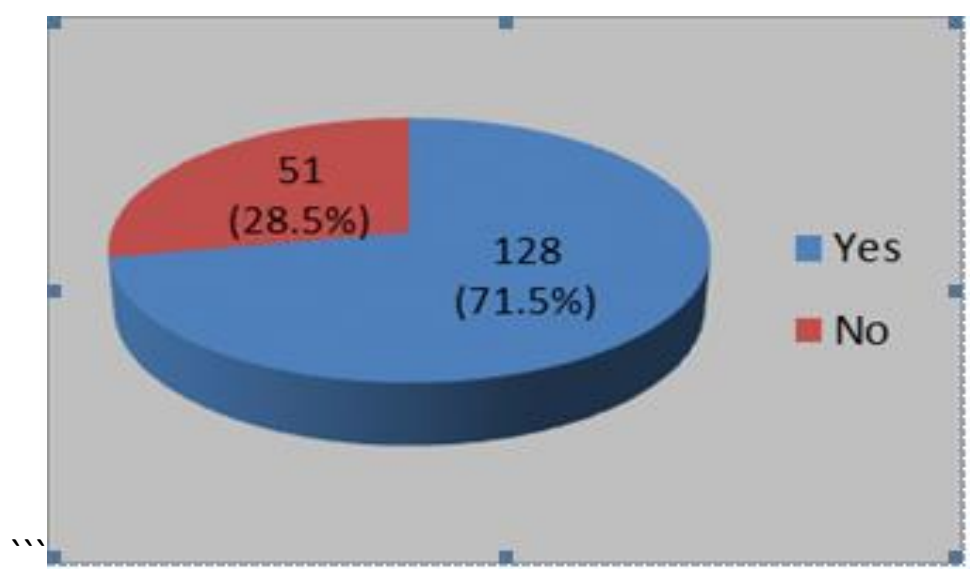

Figure 3: Have you or your neighborhood had experience with the municipal court?

Source: Survey result, 2019

Table 14: Public perception regarding Municipal court decisions and trials

\begin{tabular}{|c|c|c|c|c|c|c|c|c|c|c|c|c|c|}
\hline \multirow[t]{3}{*}{ Variables } & \multirow{3}{*}{$\begin{array}{l}\text { Respon } \\
\text { dents }\end{array}$} & & & & & & & & & & & \multirow{2}{*}{\multicolumn{2}{|c|}{ Total }} \\
\hline & & \multicolumn{2}{|c|}{$\begin{array}{c}\text { Strongly } \\
\text { agree }\end{array}$} & \multicolumn{2}{|c|}{ Agree } & \multicolumn{2}{|c|}{$\begin{array}{c}\text { Uncertai } \\
\mathrm{n}\end{array}$} & \multicolumn{2}{|c|}{ Disagree } & \multicolumn{2}{|c|}{$\begin{array}{l}\text { Strongly } \\
\text { Disagree }\end{array}$} & & \\
\hline & & $F$ & $\%$ & $\mathrm{~F}$ & $\%$ & $F$ & $\%$ & $F$ & $\%$ & $F$ & $\%$ & $\mathrm{~F}$ & $\%$ \\
\hline \multirow{3}{*}{$\begin{array}{l}\text { Decisions } \\
\text { were } \\
\text { independent } \\
\text { and } \\
\text { impartial }\end{array}$} & Male & 10 & $7.8 \%$ & 12 & $9.4 \%$ & 2 & $1.6 \%$ & 18 & $14.1 \%$ & 20 & $15.6 \%$ & 62 & $48.4 \%$ \\
\hline & Female & 0 & $0.0 \%$ & 25 & $19.5 \%$ & 3 & $2.3 \%$ & 16 & $12.5 \%$ & 22 & $17.2 \%$ & 66 & $51.6 \%$ \\
\hline & Total & 10 & $7.8 \%$ & 37 & $28.9 \%$ & 5 & $3.9 \%$ & 34 & $26.6 \%$ & 42 & 32.8 & $\begin{array}{r}12 \\
8\end{array}$ & $100 \%$ \\
\hline \multirow{3}{*}{$\begin{array}{l}\text { Cases are } \\
\text { processed } \\
\text { quickly }\end{array}$} & Male & 5 & 3.9 & 8 & $6.2 \%$ & 2 & $1.6 \%$ & 19 & $14.8 \%$ & 28 & $21.9 \%$ & 62 & $48.4 \%$ \\
\hline & Female & 3 & $2.3 \%$ & 5 & $3.9 \%$ & 11 & $8.6 \%$ & 30 & $23.4 \%$ & 17 & $13.3 \%$ & 66 & $51.6 \%$ \\
\hline & Total & 8 & $6.2 \%$ & 13 & $10.2 \%$ & 13 & $10.2 \%$ & 49 & $38.3 \%$ & 45 & $35.2 \%$ & $\begin{array}{r}12 \\
8\end{array}$ & $100 \%$ \\
\hline
\end{tabular}

Source: Survey result, 2019

According to the data in the above table, 14 respondents who had experience with the court disagreed with the view that court decisions were independent and impartial. This means, around $34(26.6 \%)$ and $42(32.8 \%)$ of male and female respondents responded as disagree and strongly disagree respectively. The information obtained from FGD with key informants also confirmed a lack of impartiality in court decisions. Most of the time justice inclined to the rich individuals, a bribe coming from these groups was a major source of injustice according to the interview. Another factor that influences court decisions was favoritism to relatives and friends. 
As can be seen in the same table majority of respondents both male and female, also disagreed with the view that court trials or cases were processed quickly in the court. This means, around 49 (38.3\%) and 45 (35.2\%) of male and female respondents believe that there was a delay in the court process. Therefore, the research confirmed that court decisions are impartial and trials lack quick processing.

Table 15: Public perception of corruption in municipal court

\begin{tabular}{|c|c|c|c|c|c|c|c|c|c|c|c|c|}
\hline \multirow{3}{*}{$\begin{array}{l}\text { Responde } \\
\text { nts }\end{array}$} & \multicolumn{10}{|c|}{ Decisions were not subject to corruption } & \multirow{2}{*}{\multicolumn{2}{|c|}{ Total }} \\
\hline & \multicolumn{2}{|c|}{$\begin{array}{c}\text { Strongly } \\
\text { agree }\end{array}$} & \multicolumn{2}{|c|}{ Agree } & \multicolumn{2}{|c|}{ Uncertain } & \multicolumn{2}{|c|}{ Disagree } & \multicolumn{2}{|c|}{$\begin{array}{l}\text { Strongly } \\
\text { Disagree }\end{array}$} & & \\
\hline & $\mathrm{F}$ & $\%$ & $\mathrm{~F}$ & $\%$ & $\mathrm{~F}$ & $\%$ & $\mathrm{~F}$ & $\%$ & $\mathrm{~F}$ & $\%$ & $\mathrm{~F}$ & $\%$ \\
\hline Male & 10 & $7.8 \%$ & 8 & $6.2 \%$ & 7 & $5.5 \%$ & 13 & $10.2 \%$ & 24 & $18.8 \%$ & 62 & $48.4 \%$ \\
\hline Female & 0 & $0.0 \%$ & 1 & $0.8 \%$ & 9 & $7.0 \%$ & 38 & $29.7 \%$ & 18 & $14.1 \%$ & 66 & $51.6 \%$ \\
\hline Total & 10 & $7.8 \%$ & 9 & $7.0 \%$ & 16 & $12.5 \%$ & 51 & $39.8 \%$ & 42 & $32.8 \%$ & $\begin{array}{r}12 \\
8\end{array}$ & $100.0 \%$ \\
\hline
\end{tabular}

Source: Survey result, 2019

The data in the above table 15 portrays the perception of the town people regarding corruption in the municipal court. According to the data in the above table, a high level of corruption prevails in the municipal court. Around 51 (39.8\%) and 42 (32.8\%) of male and female respondents were reported to disagree and strongly disagree with the view that court decisions were not subject to corruption. Thus, the result of the research has confirmed that there is a high public perception of corruption in municipal court.

\section{Public View of Corruption in Bonga Town Administration}

Table 16: The extent to which corruption is a problem in the town

\begin{tabular}{|c|c|c|c|c|c|c|}
\hline \multirow[t]{3}{*}{ Gender of respondents } & \multicolumn{4}{|c|}{$\begin{array}{c}\text { To what extent do you think that } \\
\text { corruption is a problem in Bonga town? }\end{array}$} & \multicolumn{2}{|c|}{ Total } \\
\hline & \multicolumn{2}{|c|}{ To a large extent } & \multicolumn{2}{|c|}{ To some extent } & & \\
\hline & $\mathrm{F}$ & $\%$ & $\mathrm{~F}$ & $\%$ & $\mathrm{~F}$ & $\%$ \\
\hline Male & 58 & $32.4 \%$ & 36 & $20.1 \%$ & 94 & $52.5 \%$ \\
\hline Female & 37 & $20.7 \%$ & 48 & $26.8 \%$ & 85 & $47.5 \%$ \\
\hline Total & 95 & $53.1 \%$ & 84 & $46.9 \%$ & 179 & $100.0 \%$ \\
\hline
\end{tabular}

Source: Survey result, 2019 
All respondents reported that corruption is a problem in Bonga town. Around 95 (53.1\%) of male and female respondents perceived that to a large extent corruption is a problem in Bonga town. Similarly around 84 (46.9\%) of male and female respondents were responded to some extent to the view that corruption is a problem in Bonga town. Therefore, corruption was found to be high in the study area.

Table 17: Reasons for paying a bribe

\begin{tabular}{|l|l|c|c|}
\hline Item & & $F$ & $\%$ \\
\hline $\begin{array}{l}\text { What do you think was the } \\
\text { reason for paying a bribe? }\end{array}$ & $\begin{array}{l}\text { To avoid a problem with } \\
\text { authorities }\end{array}$ & 2 & 3.7 \\
\cline { 2 - 4 } & To speed up things & 21 & 38.9 \\
\cline { 2 - 4 } & To receive a service & 31 & 57.4 \\
\cline { 2 - 4 } & Total & 54 & 100.0 \\
\hline
\end{tabular}

Source: Survey result, 2019

Respondents who have experience either in paying a bribe or knowing individuals who have paid a bribe were asked to indicate a major reason why bribe is paid. Based on this, as shown in table 17 above the frequently reported reason for paying a bribe is to receive a service which is about 31 (57.4\%). The second biggest reason for paying bribes was to speed up things. Furthermore, the response from the open-ended question and interview coupled with FGD result enlightened the following specific reasons for paying a bribe in the town:

- To get a kebele residential identity card. Many research participants reported that formally getting kebele residential card is tiresome and time-consuming.

- To get a license (especially trade)

- For transfer within (getting a promotion) and between public sectors (offices)

- To get a place for investment

- To build a house in an illegal place

Table 18: Have you ever attempted to expose corrupt officials

\begin{tabular}{|c|r|rr|}
\hline \multirow{2}{*}{ Response } & \multicolumn{3}{|c|}{$\begin{array}{c}\text { Have you ever attempted to expose corrupt } \\
\text { officials? }\end{array}$} \\
\cline { 2 - 4 } & F & \multicolumn{2}{|c|}{$\%$} \\
\hline Yes & 4 & 92.6 \\
\hline No & 50 & & 100.0 \\
\hline Total & 54 & & \\
\hline
\end{tabular}

Source: Survey result, 2019 
The data in table 18 above suggest a very low attempt at exposing corrupt individuals to the concerned local government body. Among respondents who knew a corrupt person, preponderance respondents about 50 (92.6\%) haven't attempted to expose corrupt officials/individuals in their locality. Only 4 (7.4\%) of respondents tried to expose corrupt individuals, and some of them suggested that they couldn't make headway. Thus, it is concluded that knowing that corruption is undertaking respondents remain silent without attempting to expose corrupt individuals.

Table 19: Factors for not exposing corrupt officials

\begin{tabular}{|l|l|r|r|}
\hline Item & & $F$ & \multicolumn{1}{|c|}{$\%$} \\
\hline $\begin{array}{l}\text { What was your reason for } \\
\text { not exposing corrupt } \\
\text { officials? }\end{array}$ & It will not have help at all & 9 & 18 \\
\cline { 2 - 4 } & It will take time & 2 & 4 \\
\cline { 2 - 4 } & Fear of reprisal & 39 & 78 \\
\cline { 2 - 4 } & Total & 50 & 100 \\
\hline
\end{tabular}

Source: Survey result, 2019

Fear of reprisal is one of a chief factor which was frequently reported by respondents as a reason for not exposing corrupt officials. About 39 (78\%) of respondents affirmed that fear of reprisal is a deterring factor for not exposing corrupt officials. Some others around $9(18 \%)$ of sample respondents responded that exposing corrupt officials will not have help. The remaining 2 (4\%) of respondents consider it as time-consuming. In the open-ended question, some respondents also added that they don't know where to report corrupt individuals. Even some respondents pointed out that they didn't attempt to expose corruption and they will not do so in the future too. This is because as per the viewpoint of respondents, accused officials of corruption are left to change administrative positions or transfer to another sector without being legally prosecuted and punished. Similarly the research result of Gebreslassie (2012), also pointed that "When a leader of a woreda distrusted of corruption and lose an acceptance from the people he/she can only change to the other woreda.

Large numbers of respondents were dissatisfied with the government's effort of decreasing or suppressing corruption in the town. This means, about 112 (62.6\%) of respondents were dissatisfied. Similarly about, 49 (27.4\%) of male and female respondents were strongly dissatisfied with the effort of the local government in combating corruption. Thus, according to the research result, it is possible to conclude that, though there is a high public perception of corruption in the town, government effort in suppressing corruption was found to be very low. 
Table 20: Citizens were asked to indicate their level of satisfaction regarding the local government's effort in combating corruption in the town

\begin{tabular}{|c|c|c|c|c|c|c|c|c|c|c|}
\hline \multirow[t]{3}{*}{ Respondents } & \multicolumn{8}{|c|}{$\begin{array}{c}\text { How satisfied are you with the government's } \\
\text { efforts to decrease or suppress corruption in your } \\
\text { town? }\end{array}$} & \multirow{2}{*}{\multicolumn{2}{|c|}{ Total }} \\
\hline & \multicolumn{2}{|c|}{ Satisfied } & \multicolumn{2}{|c|}{ Neither } & \multicolumn{2}{|c|}{ Dissatisfied } & \multicolumn{2}{|c|}{$\begin{array}{c}\text { Very } \\
\text { Dissatisfied }\end{array}$} & & \\
\hline & $\mathrm{F}$ & $\%$ & $\mathrm{~F}$ & $\%$ & $\mathrm{~F}$ & $\%$ & $\mathrm{~F}$ & $\%$ & $\mathrm{~F}$ & $\%$ \\
\hline Male & 3 & $1.7 \%$ & 4 & $2.2 \%$ & 67 & $37.4 \%$ & 20 & $11.2 \%$ & 94 & $52.5 \%$ \\
\hline Female & 8 & $4.5 \%$ & 3 & $1.7 \%$ & 45 & $25.1 \%$ & 29 & $16.2 \%$ & 85 & $47.5 \%$ \\
\hline Total & 11 & $6.1 \%$ & 7 & $3.9 \%$ & 112 & $62.6 \%$ & 49 & $27.4 \%$ & 179 & $100.0 \%$ \\
\hline
\end{tabular}

Source: Survey result, 2019

Municipal service provision (pure water supply \& refuse collection services)

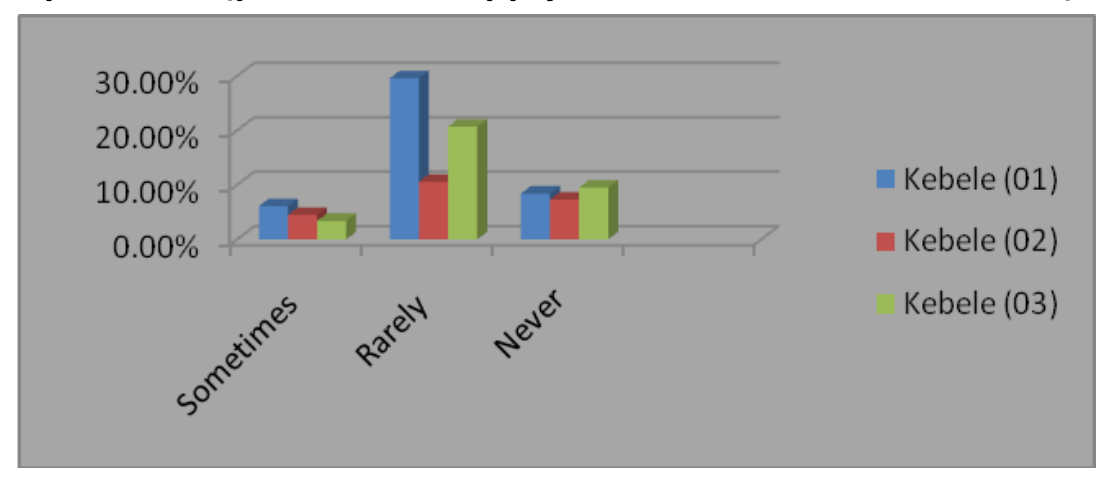

Figure 4: Access to pure water

Source: Survey result, 2019

The above figure 4 suggests that about 109 (60.9\%) of respondents from all kebele affirmed that, they rarely get pure water supply in the town. About 45 (25.1\%) of sample respondents of all kebele also responded that they never have access to pure water. Only 25 (14\%) of respondents replied that sometimes they get water from the town for their household consumption. Through open-ended questions respondents who responded "rarely" and "never" were asked to refer how they address water demand for their household consumption. Accordingly, the majority of respondents identified rainwater as their major source of water especially during the rainy season, well water which is found by digging a hole for excavating underground water, even majority of households have wells as the researchers obtained from FGD. A regular major source of water for the majority of households is spring water, where some are built (protected) by charity organizations and others are unprotected. 
In line with this, respondents were asked to offer opinions regarding their access to refuse collection service. Surprisingly, all respondents $100 \%$ reported that they haven't access to garbage collection services. This means they did not get waste collection service from the municipality. The information obtained from key informants through interviews and the FGD result figured out that, the biggest problem which is highly messing the image of the town is a dry waste. Concretizing this, FGD participants pointed out that, "people throw the dead body of domestic animal on the street and the body stays for days even for weeks without being picked". Even participants don't believe the real functioning of the municipality regarding sanitation services. Due to this majority of households manage dry wastes (garbage) by digging pit hole for collecting garbage in one place and then burning it, disposing around the fence, street, and in the ditches. Some others also responded that they dispose of the collected waste by laborers paying money; however, they are uncertain regarding the place where the laborer dumps the garbage. Moreover, according to the interview result with the spokesperson of the municipal council and municipality head the town lacks a professionally led office to keep the town clean and beautiful.

Table 21: public satisfaction on municipal service provision

\begin{tabular}{|c|c|c|c|c|c|c|}
\hline \multirow[t]{3}{*}{ Kebele } & \multicolumn{4}{|c|}{$\begin{array}{l}\text { How satisfied are you with the overall service } \\
\text { provision of the municipality regarding pure } \\
\text { water supply and refuse collection? }\end{array}$} & \multirow{2}{*}{\multicolumn{2}{|c|}{ Total }} \\
\hline & \multicolumn{2}{|c|}{ Dissatisfied } & \multicolumn{2}{|c|}{$\begin{array}{c}\text { Very } \\
\text { Dissatisfied }\end{array}$} & & \\
\hline & $\mathrm{F}$ & $\%$ & $\mathrm{~F}$ & $\%$ & $\mathrm{~F}$ & $\%$ \\
\hline Kebele (01) & 32 & $17.9 \%$ & 47 & $26.3 \%$ & 79 & $44.1 \%$ \\
\hline Kebele (02) & 14 & $7.8 \%$ & 26 & $14.5 \%$ & 40 & $22.3 \%$ \\
\hline Kebele (03) & 18 & $10.1 \%$ & 42 & $23.5 \%$ & 60 & $33.5 \%$ \\
\hline Total & 64 & $35.8 \%$ & 115 & $64.2 \%$ & 179 & $100.0 \%$ \\
\hline
\end{tabular}

Source: Survey result, 2019

All sample respondents of the research were dissatisfied with the overall service provision of the town administration. This means, about 64 (35.8\%) and 115 (64.2\%) of respondents were responded as dissatisfied and very dissatisfied respectively regarding the overall service provision of the municipality especially pure water supply and refuse collection. 


\section{CONCLUSION}

In practice, as evidenced by this research administrative decisions are not open to the people, the public office's information is less accessible, and also there is a gap between the local government and its people. The local government has a low level of consultation with its people concerning various affairs of the community. In this regard, respondents reported as they are disengaged in municipal budget consultations; indeed, the budget proposal is not announced to the people publicly affecting transparency in local government.

Concerning public participation, it is perceived that local government representatives are not keen enough on encouraging people to participate. This means the local governance seems less participatory; despite participatory governance is one of the key components of good governance which has been included in definitions of good governance. Citizens have little say in service provision and prioritization of shared problems in Bonga town. However, the finding enlightens that citizens have relative freedom in expressing their opinions in public and have active participation in elections. Whereas, public meeting attendance in the past 12 months was found to be low affecting the premises of participatory governance in which citizens are required to be engaged in public venues (common public affairs) at a variety of times throughout the year.

Various factors were identified which had been contributed to low public meeting attendance as mentioned below.

- Agendas always flow from top to down

- Most of the town agendas are predefined

- Similar issues frequently raised in public meetings and consultations

- Unresponsiveness of local government, due to this people are less interested to take part in public affairs

- Citizens perceive that attending a meeting has no value

- Local authorities don't encourage the people to take part in public affairs

- Public officials and authorities are not keen enough in mobilizing the people for participation

- Discriminating and discouraging those who speak the truth and try to expose wrongdoings

Besides, in the town administration, court decisions lack impartiality and are subject to corruption. In general, corruption is high in the administration and also people lack courage in exposing corruption because of fear of reprisal.

The town people have little access to pure water. The majority of households rarely get access to pure water. Instead, protected spring water which is built by charity organizations in collaboration with the community, and unprotected spring water, well water, and in the rainy season rainwater are major sources for the majority of households. There is no refuse collection service in the town administration. Besides, according to the interview result with the municipal 
councilors and municipality head the town lacks professionally-led office to keep the town clean and beautiful. In addition to this though, discussions/public conferences are made between the local government and people regarding good governance, problems raised remain unsolved. Public discussions are made only for the sake of formality.

\section{RECOMMENDATION}

The town administration has to ensure the accessibility of information to the people. To this end, the local government has to set clear strategies to disseminate information to service users. Disseminating information via community mass media and making people aware through regular public meetings are some of the methods which will be helpful to the local administration.

The local government has to hold regular and sustainable consultation with its town people regarding various affairs of the people (service delivery, development planning, and prioritization of public needs to mention some).

The local government has to ensure financial transparency and accountability, by allowing public representatives participation in budget consultations and regularly announcing budget proposal through posting it on places where people can easily access and see them.

The town people's concerns of municipal service provision have to be addressed; this can be done by improving the accessibility of pure water supply, availing refuse collection service, and developing the capacity of the municipality.

In general, in the town administration, there has to be regular consultation regarding good governance issues. This will help local government representatives to make themselves close to the people, get feedback, and tackle challenges of good governance in collaboration with people.

Finally, the researchers kindly advise interested researchers to investigate challenges of good governance at local level administration focusing on municipalities and service delivery issues.

\section{REFERENCE}

Aburaida, L. (2020). Obstacles Facing Rural Women's Development in Palestinian Society:

Nablus Governorate as a Case Study. Journal of Culture and Values in Education (JCVE).

AfDB. (1999). Bank Group Policy on Good Governance. Retrieved April 4, 2014, fromhttp://www.afdb.org/fileadmin/uploads/afdb/Documents/Policy-Documents/21-

EN Bank_Group_Policy_on_Good_Governance.pdf.

Belton, R. (2005). Competing Definitions of the Rule of Law: Implications for Practitioners.

Washington, Dc: Carnegie Endowment for International Peace.

Carino, L. (2000). The Concept of Governance, From Government to Governance, Reflections on the 1999 World Conference on Governance, EROPA. 
Cendon, A. (1999). Accountability and Public Administration: Concepts, Dimension, Developments.

Chernet, T. (2008). Land Resource and Socio-economic Report of Bonga, Boginda, Makira, and the Surrounding Areas in Kaffa Zone, SNNPRS, Ethiopia. Addis Ababa.

Cohen, B. (2004). Urban Growth in Developing Countries: A Review of Current Trends and a Caution Regarding Existing Forcast. World development, 23-51.

Dawson, C. (2002). Practical Research Methods: A user-friendly guide to mastering research techniques and projects. Trowbridge: How To Books Ltd.

Farrokhi, F. (2012). Rethinking Convenience Sampling: Defining Quality Criteria. Academy Publisher, 784-792.

Gebreslassie, K. (2012). Challenges of Good Governance in Local Government: The Case of Saesietsaedanba Woreda, Tigray Region, Ethiopia. International Journal of Research in Commerce, Economics, and Management.

Gisselquist, R. (2012). Good Governance as a Concept, and Why This Matters for Development Policy. Helsinki: UN-WIDER.

Global Campaign on Urban Governace. (2004, July). Retrieved April 4, 2014, from

http://ww2.unhabitat.org/campaign/governance/documents/urban\%20GovernanceEn glish-july04.pdf.

Grindle, M. (2007). Good Enough Governance Revisited. Development Policy Review 553-574.

Grindle, M. (2010). Good Governance: The Inflation of an Idea. Working Papers, Center for International Development at Harvard University. Retrieved April 2, 2014, fromhttp://www.hks.harvard.edu/var/ezp site/storage/fckeditor/file/pdfs/centersprograms/centers/cid/publications/faculty/wp/202.pdf

Heffernan, O.International Covenant on Civil and Political Rights: International Human Rights Law in Ireland. Dublin: Brehon Publishing

Idowu, S., Ifedayo, T., \& Idowu, E. (2020). Assessing the Career Conflict Options of Senior Secondary School Students of Ado-Odo Ota Local Government, Ogun State, Nigeria. Research in Social Sciences and Technology (RSSAT), 5(3).

McGee, J. \& Gaventa, R. (2010). Review of Impact and Effectiveness of Transparency and Accountability Initiatives: Prepared for the Transparency and Accountability Initiatives Workshop. London: Institute of Development Studies.

Kumar, R. (1999). Research Methodology: A Step-By-Step Guide for Beginners. London: SAGE Publications Ltd.

Lengseth, P. (1999). Prevention: An Effective Tool to Reduce Corruption. Vienna: UN.

MoFED. (2009). Financial Transparency and Accountability Perception Survey. Addis Ababa.

Nwekeaku, C. (2014). The Rule of Law, Democracy, and Good Governance in Nigeria. Global Journal of Political Science and Administration, 26-35.

OSI. (2004). Local Governance Brief: Anti Corruption at the Crossroad. Budapest, Hungary: Arktisz Ltd. 
RAND. (2008). Accountability of Teachers: Literature Review. Cambridge: RAND Corporation.

Rodden, J. \& Wibbes, E. (2012). Responsiveness and Accountability in Local Governance and Service Delivery: An Agenda for USAID Program Design and Evaluation.

Sohall, M. \& Cavills, S. (2010). Corruption in social services and human development: water, sanitation, and electricity sectors. IN: Rajivan, A.K. and Gampat, R. (eds.). Perspectives on Corruption and Human Development (vol 1), pp. 566-657.

Tegene, G.E. \& Kassahun, B. (2007). A Literature Review of Decentralization in Ethiopia. In Taye, A. \&Tegene, G.E (Eds) Decentralization in Ethiopia (p. 55). Addis Ababa: Fss.

Tiwari, A. (2004). Transparency and Accountability in Administration.

UNDP. (2007). Governance Indicator: A User Guide.

UN-HABITAT. (2002). The Global Campaign on Urban Governance, Concept Paper. Nairobi. United Natios. (2008). Participatory Governance and the Millennium Development Goals (MDGs). New York: United Nations Publication.

UN-HABITAT (2009b). Good Urban Governance: Towards an Effective Private Sector Engagement. Background Paper-Draft 0.

Wampler, B. \& McNuty, S. (2004). Does Participatory Governance Matter? Exploring the Nature and Impact of Participatory Reforms. Washington, DC: Woodrow Wilson International Center for Scholars. 